\title{
Detainees' perception of the doctors and the medical institution in Spanish police stations: An impediment in the fight against torture and ill-treatment
}

\author{
Hans Draminsky Petersen, MD*, Benito Morentin, MD, PhD**
}

\section{Key messages}

- Doctors' professional performance in Spanish police stations as perceived by most detainees was grossly insufficient.

- In general, doctors did not manage to establish an atmosphere of confidence. They were often perceived not to be neutral or independent, and even as cooperating with the police.

- Expressed threats of reprisals for telling the doctors about ill-treatment seems to have been commonplace.

- Although there has been some improvement after 1991, in comparison to before, the medical institution in police stations still fails to constitute a means to prevent torture and ill-treatment.

- The medical examination of detainees and its implementation in some police stations in Spain that deal with incommunicado detentions should be reorganised. The Spanish National Preventative Mechanism has an important role in this process and ensuring that necessary changes are implemented.

\section{Abstract}

Background: As part of a program by the Basque Government (Spain) and the University of the Basque Country, persons who have alleged exposure to torture and ill-treatment have been examined by psychol- ogists and psychiatrists according to the Istanbul Protocol (IP). Medical examinations of detainees with the aim, inter alia, to document abuses is fundamental for torture prevention. The IP prescribes how this should be done to ensure data collection and prevent reprisals for having reported ill-treatment to the doctor. Objectives: The objectives were to assess detainees' perception of the medical examinations which they underwent at different types of Spanish police institution and to compare practice between institutions; and, to compare information from the period 1969-1991 with that from 1992-2014. Methods: All information about medical examinations of incommunicado detainees from 202 extensive IP reports was analysed according to a 19-item tool developed for the purpose dealing with the doctors' professional performance, the confidence of the detainees in the doctors, reprisals and procedural safeguards (Annex 1). All information was classified as acceptable, unacceptable /insufficient or totally unacceptable. Findings: Very often the detainees perceived the doctors' professional

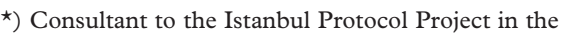
Basque Country (IPP-BC) Working Group

$\star \star)$ Section of Forensic Pathology, Basque Institute of Legal Medicine, Spain. University of the Basque Country

Correspondence to: hdp@dadlnet.dk
} 
performance as insufficient or totally unacceptable and the doctors did not instil their confidence. Threats of police reprisals and failure to observe procedural safeguards were often reported. There were no differences in the comparison between institutions. When comparing the two study periods an improvement was found over time. However, $64 \%$ of the scores came out as totally unacceptable or insufficient for the most recent period indicating that the medical institution in police stations where the detentions had taken place failed to constitute a preventive means against torture and ill-treatment. Limitations: Only 57\% of the 202 reports assessed contained relevant information; data was retrieved retrospectively; the interviews were done years after detention without a particular focus on medical examinations.

Keywords: Spain, torture, ill-treatment, medical examinations, Istanbul Protocol, detainees' perception, quality, forensic doctors

\section{Introduction}

The European Committee for the Prevention of Torture (CPT) has on many occasions visited Spanish police stations and has repeatedly concluded that they found credible and consistent allegations of ill-treatment (European Committee for the Prevention of Torture, various). In 2004 the United Nations' (UN) Special Rapporteur on Torture stated that in Spain "torture is more than sporadic and incidental" (UN report of the Special Rapporteur, 2004). Likewise, civil society organisations have collected information on torture and ill-treatment in Spanish police stations, e.g. Amnesty International, 1980; Morentin, Callado, \& Idoyaga, 2008; and, Perez-Sales, Morentin, Barrenetxea, \& Navarro-Lashayas, 2016. An official report of the Basque
Government estimates that there has been 5500 public allegations of torture and ill-treatment in the Basque Country in the period between 1960 and 2013 (Basque Government, 2013).

Generally, an incentive to carry out torture and ill-treatment exists if the ensuing confession of a crime carries heavy weight in the verdict of the court, which is the case in Spain. On the other hand, Spain has ratified the UN Convention against Torture that obliges states to criminalise torture. Moreover, detainees are regularly examined during the period of detention by forensic doctors, who have to write medical reports about the results of the examinations. Hence, when torture and ill-treatment is applied, police officers are normally careful not to use methods that leave physical marks.

In line with this, the vast majority of Basque persons who allege torture and ill-treatment describe that they have been completely isolated and exposed to a large number of physical and psychological methods simultaneously or successively - the torturing environment - during most of the first days and nights of detention until confession (Pérez-Sales, Navarro-Lashayas, Plaza, Morentin, \& Salinas, 2016). Methods often reported consist, inter alia, of: aggressive, lengthy and repeated interrogations and being confronted with false evidence and testimonies obtained through torture and ill-treatment of other persons or with manipulated statements from the detainee; hooding and other procedures with the aim of confusing and disorientating the detainee about the date and time and the proceedings of the detention; humiliations, including nudity during interrogations; constant threats of harm to the body and rape against oneself or family members; forced witnessing of torture or listening to screams and noises resembling a torture scenario; repeated use 
of blunt violence particularly against the head and testicles; total sleep deprivation and other physiological deprivation; forced lengthy maintained standing or awkward body positions; physical exercise until exhaustion; asphyxiation procedures with a plastic bag or with water.

The Istanbul Protocol (IP) is a UN document (United Nations, 2004). It sets standards for the examination, investigation and reporting of allegations of torture and ill-treatment. The IP prescribes that, when interviewing a person who claims to have been tortured, several procedural safeguards should be taken into account. This is in order to ensure privacy during the examination and confidentiality of information, to ensure the collection of all relevant information and safeguard against pressure and threats from the police to discourage detainees from reporting ill-treatment. The IP stresses the importance of the doctor obtaining the confidence of the examinee.

The Istanbul Protocol Project in the Basque Country (IPP-BC) Working Group was created several years ago. In its first study 45 persons who had alleged torture were examined and the main conclusion was that allegations were credible (Argituz et al., 2014; Istanbul Protocol Project in the Basque Country Working Group, 2016; Navarro-Lashayas et al., 2016; Pérez-Sales et al., 2016a; Pérez-Sales et al, 2016b).

Recently, the IPP-BC Working Group has done a second investigation (requested by the Basque Government) using the IP in 202 cases of allegations of torture (see Material and methods section below). The results are being analysed.

In the first study of the IPP-BC Working Group, a qualitative analysis of the detainees perception of the medical examination was carried out (Morentin, 2014). However, a quantitative analysis of the medical examina- tion in police stations, seen from the detainees' perspective, has not been done before. The objective of the present article is to analyse quantitatively the detainees' perception of their medical examination in police custody based on the information contained in the 202 IP reports taken from the second investigation of IPP-BC Working Group.

In the current study, institutions where detainees were medically examined were classified as follows: (a) local police stations (LPS) where the individual doctor cannot be expected to have a great deal of experience in performing such examinations; (b) the Central Police Station in Madrid (CPSM) where many examinations are done by a few doctors; (c) the special anti-terrorist tribunal (the Audiencia Nacional (AN)), to which detainees are transferred before appearing in court and where they are not interrogated or physically abused. The aim was to assess whether the detainees' perception of the medical examination depended on the institution where the examinations took place. Moreover, an additional objective was to assess whether there had been improvements over time in the way medical examinations are conducted as perceived by the persons examined, taking into consideration that the CPT experts have made recommendations on the issue to the Spanish Government since its first visit in 1991. Hence, data from 1969-1991 was compared with that from 1992-2014.

In this article, medical institution denotes all aspects of medical services: relevant laws and regulations, the organisation in the Ministry of Interior and the Ministry of Health, the chain of command from the ministries to the places of detention, the implementation of laws and regulations including supervision and oversight. It also includes the doctors and their training and compliance with the 
regulations, the facilities where examinations take place, safeguards for medical confidentiality and the integrity of detainees in relation to their medical examinations.

\section{Material and methods}

Participants: The Basque Government, in collaboration with the IVAC (the Basque Institute of Criminology of the University of the Basque Country), has undertaken research on torture and ill-treatment committed by security bodies in the period 1960-2013 as part of the Peace and Coexistence Plan ('Plan de Paz y Convivencia'). IVAC has established a register of Basque people who have alleged torture and ill-treatment while held under incommunicado detention in the application of antiterrorist legislation. The report - published by the Institute in 2016 - compiled a total of approximately 3,000 allegations of torture and ill-treatment. From this compilation the IVAC, IPP-BC Working Group randomly selected 202 persons to be examined in accordance with the IP as to credibility of allegations and medical and psychological consequences of torture.

The Spanish anti-terrorism legislation (paras 509, 520bis, 527) allows for incommunicado police detention for five days, which can be extended to a total of 13 days (Spanish Criminal Procedure Code). Incommunicado detainees may be held and interrogated in LPS (local police station) for a while and later transferred to CPSM (central police station) for further interrogation or to AN (anti-terrorist tribunal). They may also be transferred directly to the CPSM for interrogation. From CPSM, detainees are transferred to AN. In all types of institution detainees should regularly be examined by forensic doctors, who write a report on each examination.
Instruments and procedure of the IP evaluation: The IPP-BC Working Group is composed of about 40 professionals, mostly from the field of mental health, affiliated to different health and human rights associations. Each case was initially evaluated by one psychiatrist or clinical psychologist who - after obtaining informed consent - conducted extensive clinical interviews following a semi-structured format based on the IP. The interviews were recorded on tape or video and transcribed. The interviews included a battery of psychological tests. The initial report was reviewed by and discussed with one or more colleagues from the group. Additional evidence, e.g, relevant reports from forensic doctors or other doctors, if available, was analysed by forensic doctors and physicians of the IPP-BC Working Group.

A final IP report included demographic and criminological data, extensive testimonies of torture and ill-treatment, coding of torture methods according to the IP, physical and psychological symptoms in relation to torture, psychological and physical findings, results of psychometric tests, psychiatric diagnoses following the International Classification of Diseases (ICD) 10th version, physical sequelae, and an assessment of the level of credibility.

Information from the IP reports; availability and assessment: The 202 extensive testimonies of the IP reports were read and all the information about medical examinations during detention in police stations was analysed. In the interviews with the ex-detainees, there had been no specific focus on the medical examination. As a consequence, relevant data for this study was incomplete and only existed in 116 reports. An IP report could contain data on medical examinations done in different institutions during the same 
detention or during different detentions if the person had been arrested more than once. Information from one detention could also cover several medical encounters in one or more institutions. In order to structure this information for the purpose of this study, a tool was developed containing 19 items (mostly based on IP recommendations) organised in four groups. Issues included in the analysis and criteria for scoring appear in Annex 1. Six items were identified describing the detainee's perception of the doctor's professional conduct; five items related to the detainees' confidence in the doctor(s) and the medical institution; two items on reprisals by the police in relation to the medical examinations; and six items related to procedural safeguards. Scoring of the items was done on the following basis: totally unacceptable (judged by the authors or expressed by the examinee), 3 points; partially unacceptable or insufficient, 2 points; and, acceptable, 1 point.

Statistical analysis: The $\chi^{2}$ test was used to compare the scoring of groups of items and the total scores from the different categories of institutions (LPS, CPSM and AN) and the two study periods (before and after 1991). All analyses were carried out using the SPSS (Statistical Package for Social Sciences) program. The chosen level of significance was $\mathrm{p}<0.05$.

Ethical issues: The data generated is currently kept on paper and in digital format, which has been approved by the Basque Agency for Data Protection (AVPD). All documentation is kept confidentially in the premises of the University of the Basque Country (UPV/ $\mathrm{EHU}$ ). The research has been reviewed and approved by the Commission for Ethics in Research and Teaching of the UPV/EHU. Informed consent from all participants has been obtained.

\section{Results}

Information on the medical examinations during incommunicado detention existed in 116 (87 men and 29 women) of the 202 IP reports. The median age of the persons at the time of detention was 25 years (range 17-66). The medical examinations took place during detentions in the period 1969 -2014 (Table 1). In six cases there was information from two detentions.

In 39 IP reports there was information about medical examinations from two or three institutions. Information came from CPSM ( $n=66), \operatorname{LPS}(n=64), \operatorname{AN}(n=17)$, hospitals $(n=10)$, and prisons $(n=4)$.

The circumstances around examinations done in hospitals (the objective being merely therapeutic) were quite different from those taking place in police custody. As an example, nine of the ten who were examined in a hospital said that police officers were present during the examination, two said that they were handcuffed and one said that officers tried to change the decision of the doctor. Four examinations were done in prisons, of

Table 1: Number of detentions in relation to periods of five years. Note: six persons had been detained several times.

\begin{tabular}{|c|c|c|c|c|c|c|c|c|c|}
\hline $\begin{array}{l}\text { Period of } \\
\text { detention }\end{array}$ & $\begin{array}{l}1969 \\
-1974\end{array}$ & $\begin{array}{l}1975 \\
-1979 \\
\end{array}$ & $\begin{array}{l}1980 \\
-1984 \\
\end{array}$ & $\begin{array}{l}1985 \\
-1989 \\
\end{array}$ & $\begin{array}{l}1990 \\
-1994 \\
\end{array}$ & $\begin{array}{l}1995 \\
-1999 \\
\end{array}$ & $\begin{array}{l}2000 \\
-2004 \\
\end{array}$ & $\begin{array}{l}2005 \\
-2009\end{array}$ & $\begin{array}{l}2010 \\
-2014 \\
\end{array}$ \\
\hline $\begin{array}{l}\text { Number of } \\
\text { detentions }\end{array}$ & 1 & 5 & 22 & 17 & 12 & 12 & 21 & 17 & 15 \\
\hline
\end{tabular}


which ill-treatment was reported by three and two said that this was ignored by the doctors.

The reading of all available information gave rise to 678 assessments/scorings of statements from the detainees about medical examinations: 277 (41\%) were considered totally unacceptable, 202 (30\%) insufficient / unacceptable and 199 (29\%) as acceptable. The scorings are shown in Table 2 and Figures 1 and 2. Table 3 gives some details about the authors' observations.

Table 2: Number of observations and scorings by item and groups of items. ('totally unacceptable', 3 points; 'partially unacceptable or insufficient', 2 points; and 'acceptable', 1 point).

\begin{tabular}{|c|c|c|c|c|}
\hline \multirow[b]{3}{*}{ ITEMS (grouped) } & \multirow{2}{*}{\multicolumn{2}{|c|}{$\begin{array}{l}\text { Number of } \\
\text { observations }\end{array}$}} & \multirow{2}{*}{\multicolumn{2}{|c|}{ Levels of scoring }} \\
\hline & & & & \\
\hline & $\mathrm{n}$ & 1 point & 2 point & 3 point \\
\hline $\begin{array}{l}\text { Items } 1-6 . \text { Doctors' professional } \\
\text { performance }\end{array}$ & 227 & $95(42 \%)$ & $51(22 \%)$ & $81(36 \%)$ \\
\hline $\begin{array}{l}\text { 1: Doctor's response to requests } \\
\text { concerning health }\end{array}$ & 44 & 17 & 6 & 21 \\
\hline $\begin{array}{l}\text { 2: Doctor's response to allegations of } \\
\text { ill-treatment }\end{array}$ & 30 & 13 & 5 & 12 \\
\hline $\begin{array}{l}\text { 3: Doctor's response to question about } \\
\text { the time }\end{array}$ & 17 & 12 & 3 & 2 \\
\hline $\begin{array}{l}\text { 4: The doctor enquired about } \\
\text { ill-treatment }\end{array}$ & 56 & 24 & 13 & 19 \\
\hline $\begin{array}{l}\text { 5: The doctor performed a physical } \\
\text { examination }\end{array}$ & 72 & 28 & 23 & 21 \\
\hline 6: Duration of the medical encounter & 8 & 1 & 1 & 6 \\
\hline $\begin{array}{l}\text { Items } 7-11 . \text { Detainees' confidence in } \\
\text { the doctor }\end{array}$ & 221 & $41(19 \%)$ & $62(28 \%)$ & $118(53 \%)$ \\
\hline 7: Detainee's confidence in the doctor & 71 & 6 & 4 & 61 \\
\hline $\begin{array}{l}\text { 8: Detainee's perception of the } \\
\text { doctor's affiliation to the police }\end{array}$ & 26 & 0 & 25 & 1 \\
\hline $\begin{array}{l}\text { 9: Detainee's perception of the } \\
\text { doctor's cooperation with the police }\end{array}$ & 18 & 1 & 11 & 6 \\
\hline $\begin{array}{l}\text { 10: Detainee's motivation to see the } \\
\text { doctor }\end{array}$ & 8 & 0 & 4 & 4 \\
\hline $\begin{array}{l}\text { 11: Detainee alleged ill-treatment to } \\
\text { the doctor }\end{array}$ & 98 & 34 & 18 & 46 \\
\hline
\end{tabular}




\begin{tabular}{|c|c|c|c|c|}
\hline Items 12-13. Reprisals & 20 & 0 & $4 \quad(20 \%)$ & $16(80 \%$ \\
\hline $\begin{array}{l}\text { 12: Threats of reprisals for reporting } \\
\text { ill-treatment to the doctor }\end{array}$ & 18 & 0 & 4 & 14 \\
\hline $\begin{array}{l}\text { 13: Reprisals for having told about } \\
\text { ill-treatment }\end{array}$ & 2 & 0 & 0 & 2 \\
\hline Items 14-19. Procedural safeguards & 210 & $63(30 \%)$ & $85(40 \%)$ & $62(30 \%)$ \\
\hline $\begin{array}{l}\text { 14: The doctor introduced him-/ } \\
\text { herself as a doctor }\end{array}$ & 39 & 4 & 21 & 14 \\
\hline 15: The doctor's general attitude & 52 & 13 & 20 & 19 \\
\hline $\begin{array}{l}\text { 16: Information about the objective of } \\
\text { the examination }\end{array}$ & 0 & 0 & 0 & 0 \\
\hline $\begin{array}{l}\text { 17: Police presence during the } \\
\text { medical examination }\end{array}$ & 46 & 14 & 21 & 11 \\
\hline 18: Place of examination & 42 & 32 & 4 & 6 \\
\hline $\begin{array}{l}\text { 19: Manner in which detainee was } \\
\text { taken to the doctor }\end{array}$ & 31 & 0 & 19 & 12 \\
\hline Items $1-19$ & 678 & $199(29 \%)$ & $202(30 \%)$ & $277(41 \%)$ \\
\hline
\end{tabular}

Figure 1: Scorings - total and for the four groups of items - related to three kinds of institutions: CPSM (Central Police Station in Madrid); AN (Audiencia Nacional); LPS (Local Police Stations).

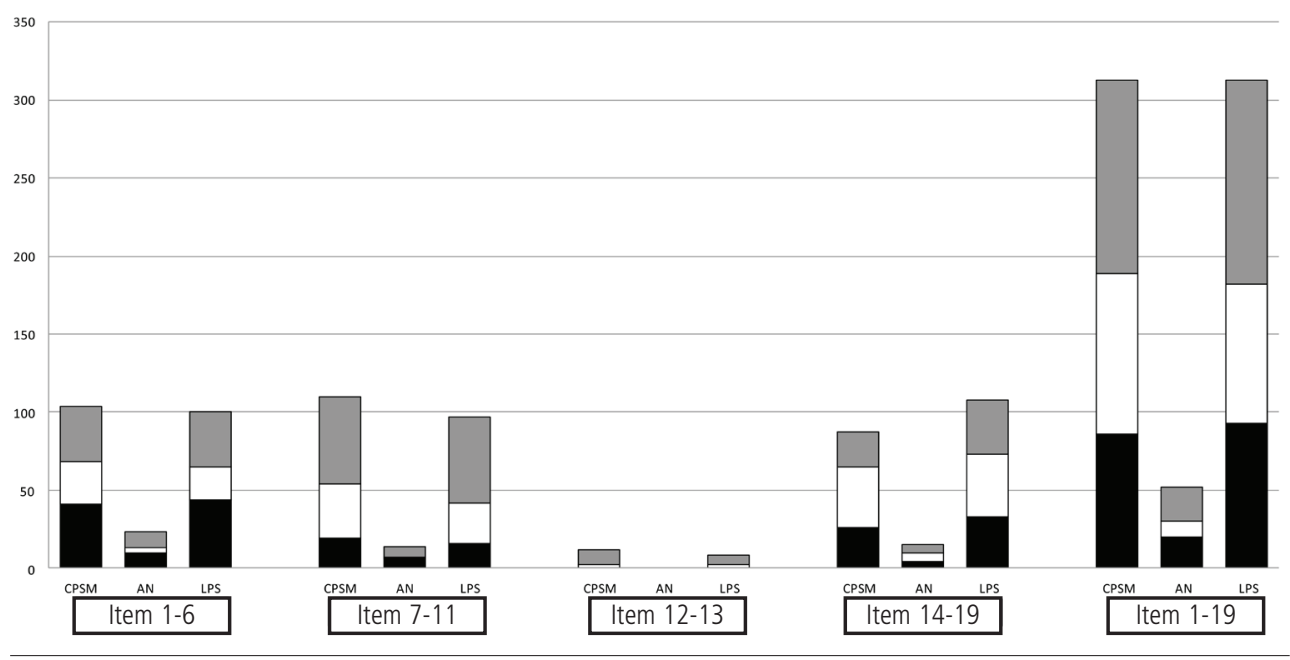

The black segment of each bar represents the cases evaluated as acceptable ( 1 point): the white segment those considered as partially unacceptable or insufficient ( 2 points): and the grey segment those considered as totally unacceptable ( 3 points). 
Figure 2: Scorings for the two study periods (until 1991 and from 1992), given by group of items and total.

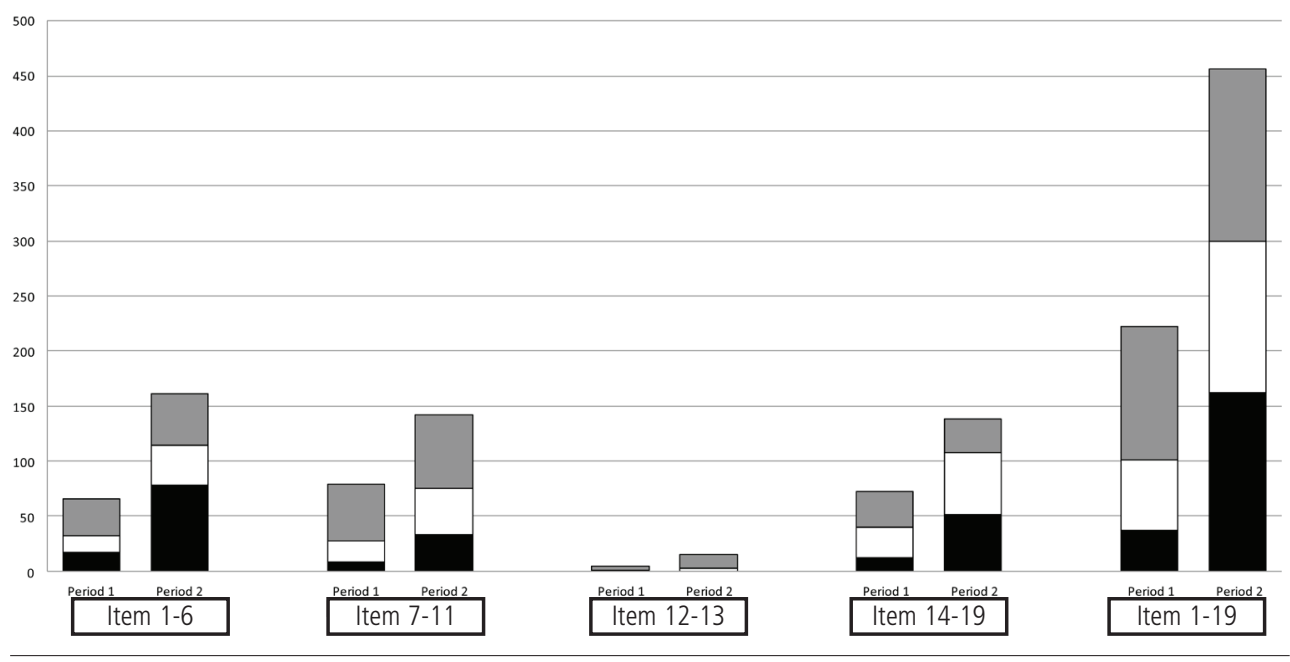

The black segment of each bar represents the cases evaluated as acceptable ( 1 point): the white segment those considered as partially unacceptable or insufficient ( 2 points): and the grey segment those considered as totally unacceptable ( 3 points).

Table 3: Some observations about individual items retrieved from the 116 (57\%) reports with available relevant information.

\begin{tabular}{cll}
\hline \multicolumn{2}{c}{$\begin{array}{l}\text { Item } \\
\mathrm{N}^{\text {o }}\end{array}$} & Issue
\end{tabular}

2 The doctor's response to allegations of torture

3 The doctor's reply to detainee's question about time and date

4 The doctor enquired about ill-treatment
Only $12 / 30$ (40\%) of the detainees were confident that the doctor entered all allegations of ill-treatment into the record. One doctor interrupted the detainee narrating ill-treatment by saying that such information should be given to the judge and not to the doctor.

Two persons said that the doctor refused to inform them about the time and date with reference to instructions from the police. In three cases the doctor did not reply, but let the person look at a watch.

In only $24 / 56(43 \%)$ of the cases does it appear that the doctor enquired explicitly about ill-treatment. In the remaining cases the doctor only did so in an ambiguous manner or not at all. 

motivation to see the doctor

11 The detainee alleged ill-treatment to the doctor
In only $28 / 72(39 \%)$ of the cases the doctors reportedly performed a full physical examination.

There was only scarce information about the thoroughness / duration of the medical encounters. A few ex-detainees said that the examination was done in a few minutes.

Total lack of confidence in the doctor was expressed in 61 cases $(86 \%)$.

One person said that he was taken to an office where a person introduced himself as a doctor. The detainee said that he had been ill-treated. The person then revealed that he was a guardia civil and warned the detainee against reporting ill-treatment next time he saw a doctor. Another reported that he identified the doctor as one of those who later took part in interrogations. 25 expressed that they saw the doctor as just another police officer.

Six ex-detainees were convinced that the doctor cooperated with the police as judged by the presence of a walky-talky switched on on the doctor's table or by the fact that officers knew the information that the detainee had given to the doctor. One person said that he heard the voice of the doctor while being subjected to suffocation. Eleven ex-detainees thought that the doctor cooperated with the police due to e.g. they observed cordial relations between the doctor and the officers, or by the fact that the doctor spoke remarkably loudly with an open door during the interview. In two cases the doctor examined the detainees several times a day and paid particular attention to the colour of their nails, which made the detainees think that the doctor was informed about the suffocation procedures that they had undergone. One said that the doctor was present in the torture room when the detainee was resuscitated after having undergone suffocation in water.

In one case - not included above - the doctor refused to believe that allegations of torture were true, but later the doctor was present during interrogations that were then remarkably little harsh (sic.).

A few declared that the only good reason for seeing the doctor was to have a break from torture or to be informed about the time and date.

46 persons $(47 \%)$ did not tell the doctor anything about the torture they had undergone because of fear of reprisals and $18 \%$ only informed the doctor on some occasions. Only 35\% reported consistently the ill-treatment they had been subjected to. 
12 Threats of reprisals for reporting ill-treatment to the doctor

Reprisals for having reported ill-treatment to the doctor

Did the doctor introduce him- / herself as a doctor

General attitude of the doctor

16 The detainee received information about objective of the examination

\section{Presence of} officers during the medical examination

19 Manner in which detainee was taken to the doctor
18 persons said that they, before the encounter with the doctor, had been threatened with reprisals if they reported ill-treatment to the doctor. The police officers in some cases mentioned that they would be informed about the content of the interview with the doctor.

Only one person said that he was further ill-treated with reference to the fact that he had told the doctor about ill-treatment. In another case the ex-detainee said that he was beaten immediately after the medical examination just outside the doctor's office and that the doctor did not appear in the corridor although he could not have missed the sounds. In one case the police interrupted the medical examination and took the detainee to interrogation and ill-treatment.

In $35 / 39(90 \%)$ of the cases the doctors did not introduce themselves in a correct manner showing an ID-card. One doctor refused to show his ID-card on the detainee's demand, which lead the detainee to refuse to cooperate to an examination. Another person said that his eyes were covered during the examination impeding him from seeing the doctor.

In only $13 / 52(25 \%)$ it appeared that the doctor's attitude was empathetic and /or interested.

This issue was included since its importance is stressed in the Istanbul Protocol. We did not find anything in the reports indicating that such information was given to any detainee.

In 11 cases it was stated that the police were present during the examination and in another 21 cases officers stood within hearing distance with the door open to the doctor's office. In 14 (30\%) of cases the examinations were reportedly done in private.

Most often medical examinations reportedly took place in on office; in a few cases in a cell or in places where there was no privacy at all. Detainees were taken to the examination by officers who participated in interrogations, and 12 stated that they were hooded or forced to bend head and body forward on the way to the doctor's office. 
Comparisons between institutions and periods of time: There were 313 scorings from CPSM, 52 from AN and 313 from LPS.

Concerning comparison of institutions, there were no statistically significant differences either in the scorings of all items together or in the comparison of groups of items (Figure 1).

There were a total of 222 scorings in the first study period and 456 in the second
(Figure 2). The scorings of all items together, the doctors' performance (items 1-6) and procedural safeguards (items 14-19) were significantly lower for the second period (Table 4).

Due to the low number of observations concerning reprisals this group was excluded from separate statistical calculations.

Table 4: Group of items with statistically significant differences concerning the two study periods $\left(\chi^{2}\right.$ test $)$.

\begin{tabular}{|c|c|c|c|c|c|c|c|c|c|}
\hline \multirow{3}{*}{$\begin{array}{l}\text { Group } \\
\text { of items }\end{array}$} & \multirow{3}{*}{ Issue } & \multirow{2}{*}{\multicolumn{3}{|c|}{$\begin{array}{c}\text { First period. } \\
\text { Levels of scoring }\end{array}$}} & \multirow{2}{*}{\multicolumn{3}{|c|}{$\begin{array}{l}\text { Second period. } \\
\text { Levels of scoring }\end{array}$}} & \multirow{2}{*}{\multicolumn{2}{|c|}{ Statistical values }} \\
\hline & & & & & & & & & \\
\hline & & $\begin{array}{c}1 \\
\text { point }\end{array}$ & $\begin{array}{c}2 \\
\text { points }\end{array}$ & $\begin{array}{c}3 \\
\text { points }\end{array}$ & $\begin{array}{c}1 \\
\text { point }\end{array}$ & $\begin{array}{c}2 \\
\text { points }\end{array}$ & $\begin{array}{c}3 \\
\text { points }\end{array}$ & $\mathrm{p}$ & $\begin{array}{c}\chi^{2} \\
\text { value }\end{array}$ \\
\hline $1-6$ & $\begin{array}{l}\text { Doctors' } \\
\text { professional } \\
\text { performance }\end{array}$ & $\begin{array}{c}17 \\
(26 \%)\end{array}$ & $\begin{array}{c}15 \\
(23 \%)\end{array}$ & $\begin{array}{c}34 \\
(51 \%)\end{array}$ & $\begin{array}{c}78 \\
(48 \%)\end{array}$ & $\begin{array}{c}36 \\
(22 \%)\end{array}$ & $\begin{array}{c}47 \\
(29 \%)\end{array}$ & 0.002 & 12.2 \\
\hline $14-19$ & $\begin{array}{l}\text { Procedural } \\
\text { safeguards }\end{array}$ & $\begin{array}{c}12 \\
(17 \%)\end{array}$ & $\begin{array}{c}28 \\
(39 \%)\end{array}$ & $\begin{array}{c}32 \\
(44 \%)\end{array}$ & $\begin{array}{c}51 \\
(37 \%)\end{array}$ & $\begin{array}{c}57 \\
(41 \%)\end{array}$ & $\begin{array}{c}30 \\
(22 \%)\end{array}$ & 0.001 & 14.8 \\
\hline $1-19$ & All & $\begin{array}{c}37 \\
(17 \%)\end{array}$ & $\begin{array}{c}64 \\
(29 \%)\end{array}$ & $\begin{array}{c}121 \\
(55 \%)\end{array}$ & $\begin{array}{c}162 \\
(36 \%)\end{array}$ & $\begin{array}{c}138 \\
(30 \%)\end{array}$ & $\begin{array}{c}156 \\
(34 \%)\end{array}$ & $<0.001$ & 33.2 \\
\hline
\end{tabular}

Scorings were: acceptable, 1 point; partially unacceptable or insufficient, 2 points; and totally unacceptable, 3 points.

\section{Discussion}

The right to a medical examination for all detainees is enshrined in resolutions of the United Nations $(1998 ; 2015)$. The medical examination in places of detention has the objective of protecting the detainee's health, which includes safeguarding against ill-treatment. A detainee should have the possibility to relate ill-treatment to an independent doctor, who should be trained to assess such allegations with respect to consistency between allegations of ill-treatment, ensuing symptoms and the results of a physical examination and a psychological assessment. Documentation of torture and ill-treatment is paramount in fighting impunity and preventing such abuses. Access to a medical examination while detained has been shown to be an important predictor for occurrence of torture and ill-treatment (Carver \& Handley, 2016). It requires that the medical examination is structured adequately and carried out accordingly, reflected in items 1-6 (Annex 1).

Other necessary requirements for such an examination to be effective in the fight against torture and ill-treatment are that the detainees trust /have confidence in the doctor, that the doctor is independent and neutral and is perceived as such and that the detainee can engage with the doctor without fear of or the risk of reprisals, reflected in 
items 7-11. Trust is an essential component of eliciting an accurate account of abuse.

Earning the trust of someone who has experienced torture or other forms of abuse requires active listening, meticulous communication, courtesy and genuine empathy and honesty. Physicians must have the capacity to create a climate of trust in which disclosure of crucial, but perhaps very painful or shameful, facts can be discussed (United Nations, 2004). Reprisals and threats of reprisals are reflected in items 12-13.

The IP prescribes a number of procedural safeguards related to the medical examination reflected in items 14-19. The doctor should introduce introduce him/ herself as a matter of accountability and establish an appropriate atmosphere during the examination. Privacy and confidentiality must exist, the place of examination must be appropriate and the transfer from the cell or interrogation room must not be intimidating.

The high number of scores that came out as unacceptable or insufficient $(71 \%)$ from all types of institution and in both periods of time clearly indicate that there were serious shortcomings in all aspects concerning the medical examination as perceived by the detainees.

There were no differences when comparing institutions.

When comparing the two study periods an improvement was found over time related to the doctors' professional performance and procedural safeguards. However, the fact that $64 \%$ of the scores came out as unacceptable or insufficient for the most recent period clearly shows that the improvements were highly insufficient. Hence, it may be inferred that the recommendations of the CPT have had only limited impact on the way medical examinations of incommunicado detainees are done in police stations according to the statements of detainees. This finding was also reflected in previous studies of forensic medical documents issued in the same categories of places of detention in Spain (Petersen, Morentin, Callado, Meana, \& Idoyaga, 2002; Morentin, Petersen, Callado, Idoyaga, \& Meana, 2008). It is also in line with statements of the CPT (CPT 2011).

The low quality of the medical examinations carried out in Spanish detention centres has been documented by different fora. For example, in 1991 and 1998 by the CPT, the European Council's Commissioner for Human rights (Muižnieks, 2013), the Ombudsman of the Basque Country (2011), by the European Court of Human Rights, (such as, Beortegui Martinez v Spain (no. 36286/14), 31 May 2016), by Amnesty International (2009), and in quantitative analyses of 743 medical documents issued in police stations (Morentin et al., 2008; Petersen et al., 2002). The present results show that, in general, the incommunicado detainees who have been medically examined in police stations share this opinion about the quality of the medical examinations.

There was consistency between observations concerning the four groups of issues: At the outset of a medical examination the doctor should, inter alia, introduce himself (group 4, procedural safeguards), which has been one of the recommendations made by the CPT to the Spanish government CPT (1994). This item scored insufficient or unacceptable in $19 / 23$ cases (83\%) in the last study period which means that, in the vast majority of cases, the doctors did not show their ID card to the detainees. Detainees may well see this as if the doctors dissociate themselves from their responsibilities and from the examinees; it is unlikely to establish an environment of confidence (group 2, confidence).

61 detainees expressed that they had no confidence in the doctors, 25 expressed that 
they saw the doctor as just another police agent, 17 thought that the doctors somehow cooperated with the police and 64 refrained totally or partially from telling the doctor about the ill-treatment they had been exposed to (group 2, confidence). It is possible to surmise that the lack of confidence is linked to the doctors' general attitude (group 4, procedural safeguards) towards the detainee, e.g. often described as uninterested, cold or hostile, and it is related to police threats of reprisals (group 3, reprisals). The environment of pressure was observed and commented upon by the CPT (June 1994, p.15): "Given the pressure that can be brought to bear on a detained person, forensic doctors should not necessarily accept the face value statements by such persons to the effect that they are being treated well".

The doctors' perceived cooperation with the police (group 2, confidence) fits the description that the medical examinations were often performed with officers within hearing distance (group 4, procedural safeguards). In addition, it was perceived that there was insufficient record keeping of allegations of ill-treatment and a lack of relevant and feasible response to detainees' request for medical treatment (group 1, professional conduct). In consonance with this, the CPT has also, from its first visit in 1991, repeatedly recommended to the Spanish government that all medical examinations should be conducted out of hearing and preferably out of sight of police or Civil Guard officers. This issue scored insufficient or unacceptable in 23/34 cases $(68 \%)$ in the last study period.

17 detainees asked the doctor to inform them of the time. In two cases the doctors replied that the police had forbidden them to give such information. In three cases the doctors did not reply, but showed their watches, which should be seen against the background of the apparently widespread practice of police agents staying within hearing distance of the encounter between the doctor and the detainee. Although the number of cases is small, it gives a clear indication that the police on some occasions have involved doctors in creating a torturing environment, which, inter alia, consists of causing total confusion and disorientation without any markers for the detainee to orientate himself/herself in the proceedings of the interrogations.

In line with this, the observations of some detainees that private information given to the doctor had become known to the police indicate that such information could be used by torturers to find personal weaknesses of detainees. This would mean that doctors on some occasions collaborated in a complex torturing environment by not observing professional confidentiality, either by performing examinations without privacy, or by providing officers with confidential information.

Whether or not the doctors accurately recorded the narrated information it remains the impression of the detainees. However, the fact that the detainees did not have any access to the content of the medical reports underlines their complete lack of all control. If the detainee during his detention had insight into the medical documents it would probably encourage the doctors to document accurately the narrated ill-treatment and symptoms and observed findings, and it would probably diminish the detainee's mistrust in the medical institution. This is also contrary to the CPT's recommendation that results of medical examinations be made available to the detainee and his lawyer (2003).

It is also noteworthy that many ex-detainees perceived the doctors as not being proactive in their collection of information on 
ill-treatment; 32/56 (57\%) of the interviewees expressed that the doctor only implicitly or did not enquire about ill-treatment at all, thereby contributing to an impression that doctors often preferred not to report ill-treatment, i.e. supporting the police.

Threats of reprisals apparently works; 18 persons said that they had been threatened not to say anything about ill-treatment; in 64 statements $(n=98)$ it appeared that the detainees refrained totally or partially from telling the doctors about ill-treatment out of fear of reprisals.

Many detainees reported that they were taken to the doctor's office by officers who participated in the interrogations. This provided an opportunity to threaten reprisals if the detainee told the doctor about the ill-treatment at a crucial moment for the detainee to establish a relationship of trust with the doctor. In line with this, many ex-detainees reported that the way in which they were taken to the doctor was threatening and humiliating, being hooded or forced to bend their head and body forward.

It is remarkable that only one person said that he was punished for having told the doctor about ill-treatment. A possible explanation is that the torturing environment is so systematic and effective that reprisals are useless for the police; however, threats are relevant since the aim is to prevent information about ill-treatment appearing in the medical documents. Absence of such information in the medical record will be contrasted with allegations of ill-treatment that later on may be reported in court. If allegations of ill-treatment and physical lesions are absent in the medical document, all allegations will most likely be considered invalid by the court (CPT 2007).

For some of the important aspects of the medical examinations, e.g. how the doctors enquired about ill-treatment and how they responded to such allegations, the statements from the ex-detainees varied significantly. This most likely reflects the lack of clear guidelines for doctors concerning their role as protectors of the detainees' rights to health and to freedom from torture and ill-treatment. This is in line with what has been concluded on the basis of analyses of 743 medical documents concerning examinations carried out in the same police stations (Petersen et al., 2002; Morentin et al., 2008).

Statistical calculations on scores of individual items were not carried out for various reasons: (a) for many of the items, the number of observations was small, which - together with what is mentioned under limitations below - would make interpretation problematic; (b) the items are interrelated within and between groups and should not be seen as individual problems; (c) eventual statistical differences may draw attention to details and away from the overall problem that the medical service in the institutions concerned should be reorganised (for a further discussion, please see the conclusion).

The 202 IP reports which make up the source of the information analysed here represent testimonies that were assessed by evaluating psychologists and physicians to be consistent and credible. Moreover, there appears to be no incentive for the ex-detainees to exaggerate or fabricate information about their experiences concerning medical examination during detention.

\section{Limitations}

The information available cannot be assumed to give a complete picture of all details of the examined persons' perception of the doctors' performance and the medical institutions in police detention; the data used here is incomplete and was retrieved retrospectively from interviews where there had been no detailed systematic questioning on the 
medical examinations in police stations. The data does however represent precise transcriptions of the ex-detainees' statements given to interviewing psychologists.

With respect to most of the interviews, many years have elapsed from the period of detention to the interview and the detainees' impressions may have been somewhat modified in the course of the years. On the other hand, torture and ill-treatment are extreme experiences and in general victims can relate many elements in great detail. Many of the reported details from the medical examinations, such as, whether the doctor introduced him-/herself, whether fear prevented the detainee from reporting torture and the conduct of the police, are very concrete and it can be supposed that they would have been remembered well. That being so, the overall content of the ex-detainees' accounts represents a fair picture of the (subjective) perception of 116 persons with respect to the manner in which the medical examinations in police stations are carried out in cases where the incommunicado detainee is suspected of having committed crimes related to activities that fell under the anti-terrorist legislation.

In $86(43 \%)$ of the IP reports there was no information on medical examinations. It may reflect that no medical examination took place or that experiences from the encounter were perceived as insignificant compared to the experiences of torture and ill-treatment. Importantly, the lack of information may also reflect that the examinees were not very critical of the medical institution, thereby distorting the results. Scores expressed as a percentage should therefore not be regarded as precise measures of prevalence.

Notwithstanding these limitations, the data allows some conclusions to be drawn given the large amount of information that was retrieved and the consistency found between subgroups of information.

\section{Conclusions}

The doctors professional performance as perceived by most detainees was grossly insufficient.

In general, the doctors did not manage to establish an atmosphere of confidence. The doctors were often perceived as not neutral and not independent and sometimes even cooperating with the police. The detainees very often feared reprisals for telling the doctor about ill-treatment.

Expressed threats of reprisals for telling the doctors about ill-treatment seems to have been commonplace

Basic procedural safeguards were not observed by the doctors in the majority of the cases.

The reported conduct of police agents is a serious problem and doctors share some of the responsibility for this by e.g. accepting to carry out medical interviews and examinations with police agents present outside an open door within hearing distance.

All of these issues constitutes serious impediments for making the medical examination in police stations an effective safeguard against torture and ill-treatment.

The problem in some police stations in Spain seems to be so systematic when dealing with incommunicado detainees that the structure of the medical examination and its implementation should be reorganised, regularly supervised by independent experts and monitored or studied in a focused and systematic manner.

The medical institution responsible for the health of the detainees, including protection against torture and ill-treatment, in police stations must be independent and seen as such by the detainees. The doctors working there should have clear instructions about their role and conduct and the content 
of a medical examination; the format for the examinations should include questions about physical as well as psychological ill-treatment and somatic and psychological symptoms, together with a full physical examination, a psychological assessment and a conclusion as to consistency between alleged ill-treatment, ensuing symptoms and objective findings. The record keeping should be meticulous.

The detainees should have a genuine opportunity to complain about ill-treatment and to be heard in court. One of the necessary prerequisites is that the detainees are informed and receive the relevant documentation. A beginning could be to give them immediate access to all medical documents made during their detention and to provide them with copies of all medical documents when they leave the police station.

Although there has been some improvements from the first to the second study period, our results clearly indicate that the medical institution in police stations still fails to constitute a preventive means against torture and ill-treatment, which we also have found previously by other means (Petersen et al., 2002; Morentin et al., 2008) and which has also been indicated by the CPT (CPT 2011). These results can be considered together with the fact that many crucial issues dealt with by the CPT in their recommendations to the Spanish government appeared to have been ignored e.g. the doctor's obligation to introduce him/herself and to conduct the examination out of hearing distance of police officers and that the detainee and his/her lawyer should be provided with the results of the medical examination (CPT 2011). This leads to the inference that the CPT has only had limited effect on the preventive function of medical examinations in police stations. The responsibility for this lies with the Spanish government.
The Spanish National Preventive Mechanism (NPM) under the Optional Protocol to the UN Convention against Torture and Other Cruel, Inhuman or Degrading Treatment or Punishment came into operation in 2010 with a mandate in many ways similar to that of the CPT. Given the study periods of the present project, a discussion of the possible impact of the visits to police stations by the NPM is not meaningful. However, the existing knowledge about the practices as to incommunicado detention - particularly those exercised under the anti-terrorist legislation - should be sufficient for the responsible ministries to rethink the structure and function of existing safeguards against ill-treatment in places of detention. The Spanish NPM has an important role in this process and ensuring that necessary changes are implemented.

\section{Acknowledgements}

Health organizations participating in the Istanbul Protocol Project in the Basque Country (IPP-BC) Working Group were Ekimen Elkartea, Asociación para el Estudio de Problemáticas Sociales, Jaiki-Hadi, Prebentzio eta Asistentziarako Elkartea, OME-AEN, Osasun Mentalaren Elkartea/ Asociación de Salud Mental y Psiquiatría Comunitaria, ARGITUZ, Asociación pro derechos humanos, Grupo de Acción Comunitaria (GAC), and Centro de Recursos en Salud Mental y Derechos Humanos.

Professionals of the IPP-BC Working Group included Ainara Iraizoz, Ana Gil, Ana Isabel Ruiz de Alegría, Brais Pereira, Eider Zuaitz, Haizea de la Llosa, Iñaki Markez, Iñigo Ibarzabal, Ion Ibañez de Opakua, Itziar Caballero, Itziar Gandarias, Ixone Legorburu, Joana Miren Ruiz, Jone Ortuondo Aresti, Josefina García de Eulate, Julene Zuazua Álvarez, Leire Celaya, Lorena Leiro, Maddi López, Maitane 
Ibernia, María Beloki, Marian Mendiola, Maribi Armendariz, Maritxu Jimenez., Mayi Sarasketa, Miguel Ángel Navarro, Myriam Ruiz, Nagore López de Luzuriaga, Norma Ormaetxea, Oihana Andueza, Olatz Barrenetxea, Pau Pérez Sales, Teresa Velasco Plaza, Urko Zalbidea, Uxoa Larramendi and Yolanda Resano.

We are also grateful to Dr. Rasmus Goll at the Department of Gastroenterology, the University Hospital of Northern Norway in Tromsø, for advice on statistical issues.
References

Amnesty International. (1980). Report of an Amnesty International mission to Spain 3-28 October 1979. London: Amnesty International Publications.

Amnesty International. (2009). Spain: Out of the shadows - time to end the incommunicado detention. London: Amnesty International Publications. Argituz, AEN, Ekimen Elkartea, GAC, Jaiki-Hadi, OME, OSALDE, Departamento de Psicología Social (UPV/EHU). (2014). Incommunicado detention and torture. Assessments using the Istanbul protocol. Bilbao: Ekimen Ed. and Irredentos Libro.

Basque Government, Presidency. (2013)Informe-base de vulneraciones de derechos humanos en el caso vasco 1960 -2013. Vitoria-Gasteis 2013; June 2013. [Database on human rights violation in the Basque Country]Retrieved from http:estaticos. elmundo.es/documentos/2013/06/14informe_ base_es.pdf

Basque Institute of Criminology of the University of the Basque Country. (2016). Instituto Vasco de Criminología. Proyecto de investigación de la tortura en Euskadi entre 1960-2010: Informe preliminar sobre diseño y primeros pasos del estudio sobre la tortura. [Project to investigate torture in the Basque Country 1960 -2010. Preliminary report on design and first steps of the study on torture] Donosti. Retrieved from http://www.eitb.eus/multimedia/ documentos/2016/06/27/1987310/Memoria $\% 20$ Proyecto\%20tortura\%202016.pdf

Carver R, Handley L (2016). Does torture prevention work? Liverpool: Liverpool University Press 2016.

European Committee for the Prevention of Torture (CPT). Reports from visits to Spain: 1-12 April 1991; 10-22 April 1994; 10-14 June 1994; 22 November - 4 December 1998; 22-26 July 2001; 22 July - 1 August 2003; 12-19 December 2005; 19 September - 1 October 2007; 31 May - 13 June 2011. Retrieved from http://www.cpt.coe.int/

Istanbul Protocol Project in the Basque Country Working Group. (2016). Incommunicado detention and torture in Spain, Part I: The Istanbul Protocol Project in the Basque Country. Torture 26(3): 3-7.

Morentin B. (2014). In Incommunicado detention and torture. Assessments using the Istanbul protocol. Bilbao: Ekimen Ed. and Irredentos Libros 2014.

Morentin B, Callado LF, Idoyaga I. (2008). A followup study of allegations of ill-treatment /torture from incommunicado detainees in Spain. Torture 18(2): 87-98. 
Morentin B, Petersen HD, Callado LF, Idoyaga I, Meana JJ (2008). A follow-up investigation on the quality of medical documents from examinations of Basque incommunicado detainees. The role of the medical doctors and the national and international authorities in the prevention of illtreatment and torture. Forensic Science International 182:57-65.

Muižnieks N (2013). Report of the Commissioner for Human Rights of the Council of Europe following his visit to Spain from 3 to 7 June 2013, para. 134. CommDH(2013)18. Strasbourg.

Navarro-Lashayas MA, Pérez-Sales P, Lopes-Neyra G, Martínez MA, Morentin B. Incommunicado detention and torture in Spain, Part IV: Psychological and psychiatric consequences of ill-treatment and torture: trauma and human worldviews. Torture 2016; 26: 34-45.

Péres-Sales P, Morentin B, Barrenetxea O, NavarroLashayas MA. (2016a). Incommunicado detention and torture in Spain, Part II: Enhanced credibility assessment based on the Istanbul Protocol. Torture 2016(3); 26: 8-20.

Pérez-Sales P, Navarro-Lashayas MA, Plaza A, Morentin B, Salinas OB. (2016b). Incommunicado detention and torture in Spain, Part III: "Five days is enough": the concept of torturing environment. Torture 26(3): 21-33.

Petersen HD, Morentin B, Callado LF, Meana JJ, Idoyaga I (2002). Assessment of the quality of medical documents issued in central police stations in Madrid, Spain: The doctor's role in the prevention of ill-treatment. J Forensic Sci 47(2):293-298.

The Basque Ombudsman /Ararteko. Estudio sobre el sistema de garantías en el ambito de la detención incomunicada y propuestas de mejora. VitoriaGasteiz 2011. http://www.ararteko.net/RecursosWeb/DOCUMENTOS/1/5_2093_3.pdf

United Nations report of the Special Rapporteur on the question of torture: Visit to Spain. 6. February 2004. E/CN.4/2004/56/Add.2.

United Nations. (1988) Body of Principles for the Protection of All Persons under Any Form of Detention and Imprisonment. A/RES/43/173. Retrieved from http://www.un.org/documents/ga/ res/43/a43r173.htm

United Nations. (2004). Manual on the effective investigation and documentation of torture and other cruel, inhuman or degrading treatment or punishment. United Nations; New York and Geneva. http://www.ohchr.org/Documents/Publications/training8Rev1 en.pdf
United Nations. (2015). Standard Minimum Rules for the Treatment of Prisoners (the Nelson Mandela Rules). 70/175. Retrieved from https://www. unodc.org/documents/justice-and-prison-reform/ GA-RESOLUTION/E_ebook.pdf 


\section{Annex 1}

\section{Tool to assess detainee's perception of the medical examination}

\begin{tabular}{|c|c|c|c|c|}
\hline & Score $>$ & $\begin{array}{l}\text { Acceptable } \\
1 \text { point }\end{array}$ & $\begin{array}{l}\text { Insufficient } \\
2 \text { points }\end{array}$ & $\begin{array}{l}\text { Unacceptable } \\
3 \text { points }\end{array}$ \\
\hline \multicolumn{5}{|c|}{ Items related to doctor's professional conduct (1-6) } \\
\hline 1 & $\begin{array}{l}\text { The doctor's } \\
\text { response to an } \\
\text { obvious health need }\end{array}$ & $\begin{array}{l}\text { Appropriate (given } \\
\text { the circumstances) }\end{array}$ & Insufficient & Absent or irrelevant \\
\hline 2 & $\begin{array}{l}\text { The doctor's } \\
\text { response to allega- } \\
\text { tions of torture }\end{array}$ & $\begin{array}{l}\text { All allegations were } \\
\text { recorded }\end{array}$ & $\begin{array}{l}\text { Something was } \\
\text { entered into the } \\
\text { record }\end{array}$ & Absent or irrelevant \\
\hline 3 & $\begin{array}{l}\text { The doctor's reply } \\
\text { to detainee's question } \\
\text { about hour and date }\end{array}$ & $\begin{array}{l}\text { The doctor gave the } \\
\text { information }\end{array}$ & $\begin{array}{l}\text { The doctor did not } \\
\text { reply, but let the } \\
\text { detainee look at his } \\
\text { watch }\end{array}$ & $\begin{array}{l}\text { The doctor refused } \\
\text { to answer referring } \\
\text { to order from the } \\
\text { police }\end{array}$ \\
\hline 4 & $\begin{array}{l}\text { The doctor enquired } \\
\text { about ill-treatment }\end{array}$ & $\begin{array}{l}\text { The doctor asked } \\
\text { specifi-cally about } \\
\text { ill-treatment }\end{array}$ & $\begin{array}{l}\text { The doctor did so in } \\
\text { an ambiguous } \\
\text { manner }\end{array}$ & $\begin{array}{l}\text { The doctor did not } \\
\text { ask at all }\end{array}$ \\
\hline 5 & $\begin{array}{l}\text { A physical examina- } \\
\text { tion was done }\end{array}$ & $\begin{array}{l}\text { A full examination } \\
\text { was done, or an } \\
\text { invitation to do so } \\
\text { was given }\end{array}$ & $\begin{array}{l}\text { Some parts of the } \\
\text { body were examined, }\end{array}$ & $\begin{array}{l}\text { No initiative to } \\
\text { perform a physical } \\
\text { examination }\end{array}$ \\
\hline 6 & $\begin{array}{l}\text { Duration of the } \\
\text { medical encounter }\end{array}$ & 30 minutes or more & $15-30$ minutes & A few minutes \\
\hline
\end{tabular}

Items related to detainees' confidence (items 7 -11)

7 Detainee's confidence in the doctor

8 Detainee's perception of the doctor's affiliation to the police

9 Detainee's perception of the doctor's cooperation with the police
Directly or indirectly Confidence expressed confidence

concerning some aspects

The detainee thought that the doctor could be a police officer

The doctor treated information confidentially and was not present during interrogations
The detainee thought - without substantiation - that the doctor collaborated
Expressed lack of confidence

The detainee observed that the doctor acted as a police officer

The detainee's observations substantiated that the doctor collaborated 
10 The detainee's motivation to see the doctor
The record could be useful or medical treatment could be given

11 The detainee alleged Reported all ill-treatment to the doctor ill-treatment in spite of risk of reprisals
The examination

was a break in

ill-treatment or an

opportunity to be

informed about time

Reported something Did not report at all at some occasions out of fear for reprisals

No motivation at all

reprisals

Items on reprisals (items $12-13$ )

12 Threats of reprisals No

for reporting

ill-treatment to the

doctor

13 Reprisals for having No

reported ill-treat-

ment to the doctor
Ambiguous message Direct threats that could be threatening

Items related procedural safeguards (items 14 -19)

14 Did the doctor introduce him- / herself as a doctor

15 General attitude of the doctor towards the detainee

16 The detainee received information about objective of the examination

17 Presence of officers during the medical examination

18 Place of examination
19 Manner in which detainee was taken to the doctor

\begin{tabular}{|c|c|c|}
\hline ID card was shown & $\begin{array}{l}\text { Orally without } \\
\text { showing an identity } \\
\text { card }\end{array}$ & No \\
\hline $\begin{array}{l}\text { Interested or } \\
\text { empathic }\end{array}$ & $\begin{array}{l}\text { Distant or lacking } \\
\text { interest }\end{array}$ & Cold or hostile \\
\hline $\begin{array}{l}\text { Information } \\
\text { included the aim of } \\
\text { documenting (ill-) } \\
\text { treatment }\end{array}$ & $\begin{array}{l}\text { Some information, } \\
\text { but not about } \\
\text { documenting (ill-) } \\
\text { treatment }\end{array}$ & $\begin{array}{l}\text { No information at } \\
\text { all }\end{array}$ \\
\hline No & $\begin{array}{l}\text { Officers within } \\
\text { hearing distance, } \\
\text { e.g. with open door } \\
\text { to doctor's office }\end{array}$ & $\begin{array}{l}\text { Officers present } \\
\text { during the medical } \\
\text { examination }\end{array}$ \\
\hline The doctors office & The cell & $\begin{array}{l}\text { Public place without } \\
\text { privacy }\end{array}$ \\
\hline $\begin{array}{l}\text { Guided by officers } \\
\text { who did not take } \\
\text { part in interrogations }\end{array}$ & $\begin{array}{l}\text { Taken by the officers } \\
\text { who interrogated }\end{array}$ & $\begin{array}{l}\text { Taken while hooded } \\
\text { or forcibly bent } \\
\text { forward }\end{array}$ \\
\hline
\end{tabular}
part in interrogations
Punishment for having reported ill-treatment 